\title{
A polêmica como interincompreensão em embates discursivos do espaço virtual
}

Jaqueline Aparecida NOGUEIRA

Márcio Rogério de Oliveira CANO

\section{Considerações iniciais}

Com este trabalho, refletimos sobre um embate discursivo materializado no ambiente virtual, visando analisar as estratégias de leitura interincompreensiva concretizadas nesse espaço. Elegemos, como base teórica principal, os trabalhos de Maingueneau $(2005,2008,2010,2015)$. O corpus de análise foi constituído por duas crônicas pertencentes a uma formação discursiva temática, na qual se fala sobre o amor. Os objetivos foram: (i) descrever as condições sócio-históricas de produção do material analisado; (ii) delinear as imagens de si construídas pelos enunciadores respon- 
sáveis pelas crônicas; (iii) identificar e analisar as estratégias linguístico-discursivas de tradução do sentido no material. Na fase analítica, empregamos a noção de interincompreensão polêmica de Maingueneau (2005) para contrastar as restrições semânticas destacadas pelo segundo discurso em relação ao primeiro. Ao final dos trabalhos, concluímos que os enunciadores tomaram posições discursivas diferentes, apesar de versarem sobre uma temática comum. $\mathrm{O}$ enunciador agente empreendeu uma leitura que gerou uma polêmica em relação aos semas privilegiados pelo enunciador paciente na tentativa de influenciar os potenciais coenunciadores em seu favor. Ademais, constatamos que o choque instaurado pelo processo de tradução de sentido pode ser associado à imagem de cada um dos enunciadores, os quais atuaram no espaço virtual em prol da construção de imagens vendáveis de si.

Acompanhamos o ambiente virtual durante o primeiro semestre do ano de 2016 para constituir o corpus. Nesse período, observamos a circulação de notícias diversas, que migravam de jornais virtuais para as mídias sociais. A atividade de transposição da maioria dos textos acompanhados apresentou uma curiosa similaridade - a maioria deles era comentada, discutido e ou respondido a partir da polêmica. Nesse contexto, selecionamos as seguintes crônicas: "Desculpe o transtorno, preciso falar da Clarice", publicado no jornal Folha de São Paulo on-line e "Desculpe o transtorno Gregorio. Preciso muito falar da Júnia”, publicado na rede social Facebook. As reflexões contribuem para a área dos estudos discursivos, pois focalizam as interações interdiscursivas nas redes sociais, cuja temática vem sendo muito discutida hodiernamente. Colaboram, também, para os estudos voltados à leitura, uma vez que demonstram como as estratégias de atribuição de sentido para um discurso primeiro podem ser variadas. Maingueneau (2015) chama a atenção para o tipo de textualidade preponderante na Web, chamada por ele de navegante. Essa noção implica em uma 
transformação da noção de leitura, pois cada internauta possui a liberdade para escolher os seus percursos, o que modifica as relações entre sujeito, autor, e texto.

Com relação ao percurso, iniciamos os estudos descrevendo as condições sócio-históricas do material analisado, onde refletimos sobre as características do ambiente virtual e as circunstâncias de enunciação de cada uma das crônicas. Em seguida, discutimos a bibliografia e as noções teórico-metodológicas adotadas. Nesse espaço, focalizamos as discussões sobre a zona do interdiscurso e a noção de polêmica interincompreensiva. Na sequência, discutimos e analisamos a construção do ethos discursivo nos discursos, pois consideramos a necessidade de compreender a linha discursiva de atuação de cada um dos comediantes antes de adentrarmos a análise das marcas linguístico-discursivas propriamente ditas. Finalmente, exploramos as traduções de sentido materializadas pela segunda crônica em relação à primeira, contrastando as grades sêmicas privilegiadas por cada enunciador.

\section{As condições sócio-históricas de produção}

De maneira geral, a análise do discurso é uma corrente que prima pela investigação do modo social de produção da linguagem. Orlandi (1988, p. 17) advoga que: "Não consideramos nem a linguagem como um dado nem a sociedade como um produto; elas se constituem mutuamente. Se assim é, o estudo da linguagem não pode estar apartado da sociedade que a produz.. Nesse sentido, destacamos a relevância de examinar as condições de produção das crônicas sob análise. Embora constituam uma espécie de diálogo indireto, elas foram publicadas por enunciadores e em diferentes locais. Ambas circularam na Internet, integrando a esfera de atividades do entretenimento. Atentos a esse ambiente virtual 
e à sua configuração convergente, que engloba diversas atividades e gêneros, destacamos as atuações da Folha de São Paulo, em seu segmento jornalístico digital, e a do Facebook, como uma rede social de proporções globais.

De acordo com Lèvy (1999), o espaço cibernético, constituído por meio da Internet e estruturado pelas tecnologias digitais, surgiu como meio de amplificar e modificar relações econômicas, sociais e culturais. Neste campo, jornais como a Folha de São Paulo vislumbraram novos mercados de atuação e, consequentemente, lançaram as suas versões online. A interatividade pode ser considerada uma das principais características do ambiente virtual. $\mathrm{Na}$ perspectiva de Emediato (2015), a presença de modalidades técnicas de interatividade representa uma das principais particularidades do Facebook e da Internet. As redes sociais são conceituadas por Emediato (2015) como redes de discursos que constituem um espaço retórico por natureza. Tal espaço, aparentemente democrático, permite que qualquer cidadão comum se expresse retoricamente sem a necessidade de pedir qualquer permissão. Essas expressões são concretizadas por meio de diversos códigos semiológicos como textos, imagens, vídeos, entre outros. Nas palavras do autor:

Podemos encontrar, nessa rede, tudo que poderíamos supor no universo de discursos e nos espaços discursivos. Múltiplas formações discursivas, relações interdiscursivas dinâmicas, diferentes gêneros do discurso, e o dialogismo em todos os seus estados. Está tudo ali (EMEDIATO, 2015, p. 172-173).

Na interação das crônicas, os coenunciadores protagonizaram um processo similar a uma interlocução dialogal, a despeito da fal- 
ta de copresença espacial natural dos espaços online. Nesse diálogo hipotético, o enunciador primeiro (Gregório Duvivier), o qual nomearemos doravante como enunciador paciente (EP), materializou uma crônica visando um leitor ideal: o público do jornal de forma geral. Posteriormente, em outro local da rede, outro enunciador (Rafinha Bastos), considerado como o enunciador agente (EA), empreendeu uma simulação de diálogo, por meio do qual respondeu diretamente o primeiro enunciador, através de uma leitura outra de seu texto. Apesar de se dirigir diretamente ao EP, o EA também visou um leitor ideal: os seus seguidores na rede social. A leitura outra concretizada por EA promoveu um choque entre posicionamentos diferentes: enquanto EP enunciou: (1) Conheci ela no jazz, EA enunciou: (2) Não conheci ela no jazz, na infância nem no ICQ". Essa exemplificação nos mostra que os efeitos de sentido construídos pelo agente exaltaram as diferenças entre os pontos de vista de um e do outro.

Considerando o contexto em que figuram, apuramos que ambas as enunciações concretizaram tanto atitudes heterocentradas, quanto egocentradas. Emediato (2015) esclarece que as atitudes heterocentradas referenciam o mundo e os discursos dos outros, deste modo, falam do mundo e dos outros. De outro modo, as atitudes egocentradas são voltadas à exibição de si no sentido mais estrito, primando pela exibição do corpo, do rosto, do espaço privado do sujeito e também de sua família ou entes próximos. $\mathrm{O}$ autor ressalta que a atitude egocentrada, a qual é dominante na rede, dirige-se ao outro e busca uma atitude responsiva apreciativa. Uma atitude heterocentrada pode expor formações discursivas e ideologias e servir ao propósito de influenciar o outro. De maneira similar, uma atitude egocentrada pode ser uma estratégia para seduzir o outro. 
Aventamos a hipótese de que ao revelar a sua história de amor com a ex-esposa, bem como a tristeza pelo término do relacionamento, EP procurou atingir o seu público através da emoção. Nessa atuação egocentrada, construiu uma imagem de bom moço que foi abandonado. Tal estratégia de captação possui motivações determinadas: a captação de expectadores para um filme ${ }^{2}$ gravado com a personagem da crônica, o qual foi lançado na semana seguinte. EA também procurou construir uma imagem positiva de si ao responder a crônica inicial. Contudo, não apelou para a emoção do público, integrando concomitantemente uma atitude egocentrada, ao exibir detalhes íntimos de sua vida, e heterocentrada, ao exaltar a sua competência axiológica. Em síntese, EA aclamou a si e menosprezou os posicionamentos de EP, na tentativa de convencer os possíveis leitores de que a sua formação ideológica era a mais contundente.

\section{A zona do Interdiscurso}

Com base na ideia de que o discurso se desenvolve no bojo do interdiscurso, todo enunciado sempre se relaciona a outro, formando uma corrente de interação verbal ininterrupta, nos termos bakhtinianos. Para discutir sobre o primado do interdiscurso, Maingueneau (2005) retomou a noção de heterogeneidade enunciativa, a qual abarca distintivamente as formas da presença do "outro" no discurso. Ao destacar a diferença residente entre a heterogeneidade mostrada e a heterogeneidade constitutiva, o autor argumentou que a sua abordagem do interdiscurso repousa justamente na perspectiva concernente à segunda noção mencionada. Ao contrário da heterogeneidade mostrada, a qual deixa marcas explícitas no fio discursivo, a heterogeneidade constitutiva não

2 Longa brasileiro Desculpe o transtorno filmado lançado no ano de 2016. 
deixa marcas visíveis, de modo que a presença do outro pode ser compreendida como "uma condição incontornável do discurso", em consonância às palavras de Authier-Revuz (1990). Segundo a autora, a presença do Outro/outro pode ser apreendida a partir de duas perspectivas: a primeira, baseada na psicanálise lacaniana, apreende a presença do Outro como a manifestação do inconsciente nos processos de linguagem ${ }^{3}$; e a segunda, ancorada nas teorias de Bakhtin e do Círculo, toma a presença do outro como um fenômeno social, considerando que o sujeito se constitui através das palavras dos outros (outros sujeitos, outros discursos, outras vozes).

Após discutir as noções de heterogeneidade mostrada e constitutiva vislumbradas por Authier-Revuz (1990) e balizar, em certa medida, a sua perspectiva de interdiscurso em Bakhtin, Maingueneau (2005) procurou direcionar a noção de interdiscurso a um quadro metodológico e a um domínio de validade mais restrito, fazendo emergir então, as noções de universo, campo e espaço discursivo. Em suas palavras, o universo discursivo diz respeito "ao conjunto de formações discursivas de todos os tipos que interagem numa conjuntura dada”. (MAINGUENEAU, 2005, p. 35). Trata-se de um conjunto finito delineado em um horizonte onde se encontram os campos passíveis de serem analisados. Já os campos discursivos podem ser compreendidos como "um conjun-

3 "O que, de fato, Freud coloca é que não há centro para o sujeito fora da ilusão e do fantasmagórico, mas que é função desta instância do sujeito que é o eu ser portadora desta ilusão necessária. É a tal posição, a da função do desconhecimento do eu que, no imaginário do sujeito dividido, reconstrói a imagem do sujeito autônomo, apagando a divisão (evidentemente inconciliável com todas as variantes de concepções do sujeito que o reduzem ao eu ou o centram sobre si próprio) a que remete o ponto de vista segundo o qual "o centro é uma ilusão produzida para o sujeito, que as ciências do homem [e no nosso campo, as teorias da enunciação] tomam como objeto ignorando que ele é imaginário'” (AUTHIER-REVUZ, 1990, p. 28-29). 
to de formações discursivas que se encontram em concorrência, delimitando-se reciprocamente em uma região do universo discursivo" (MAINGUENEAU, 2005, p. 35). O autor esclarece que a concorrência de que fala compreende tanto as relações conflitantes, quanto as conciliatórias, ou ainda, as aparentemente neutras. Nesse mote, o recorte proposto pela noção de campo discursivo é uma abstração necessária para a concretização das análises e deve promover o vislumbre das redes de trocas.

No interior do campo discursivo se constitui um discurso (MAINGUENEAU, 2005). O autor levanta a hipótese de que, por ser fruto de operações regulares em formações discursivas já existentes, essa constituição se deixa descrever. Em decorrência dessa possibilidade, o analista do discurso pode delimitar as suas formulações. Todavia, o autor salienta que embora sejam constituídos a partir de certa regularidade, é imprescindível considerar a vasta heterogeneidade dos discursos de um mesmo campo. Em seus dizeres: “[...] uma hierarquia instável opõe discursos dominantes e dominados e eles não se situam todos necessariamente no mesmo plano. Não é possível, pois, determinar a priori as modalidades das relações entre as diversas formações discursivas de um campo" (MAINGUENEAU, 2005, p. 36-37, itálico do autor). Devido a essa variabilidade, o autor alerta sobre a necessidade de isolar os campos em espaços discursivos, ou seja, subconjuntos de formações discursivas que serão restringidos pelo analista com base em hipóteses fundadas em conhecimentos dos textos e em saberes históricos. Tais espaços podem ser compreendidos como redes de interações semânticas.

É importante evidenciar que a problemática do interdiscurso discutida por Maingueneau (2005) difere da perspectiva adotada por outros autores, para os quais o outro equivale a um interlocutor. Em suas palavras: "Reconhecer este tipo de primado do inter- 
discurso é incitar a construir" [...] um sistema no qual a definição da rede semântica que circunscreve a especificidade de um discurso coincide com a definição das relações desse discurso com seu Outro" (MAINGUENEAU, 2005, p. 38, itálico do autor). Para Maingueneau, o outro, o qual também não coincide com o Outro lacaniano, não seria um fragmento localizável, uma citação, ou mesmo um elemento exterior, seria, como denota a palavra "constitutivo", inscrito na raiz do discurso: “[...] aquela parte de sentido que foi necessário que o discurso sacrificasse para constituir sua identidade" (MAINGUENEAU, 2005, p. 39). O estudioso defende que um discurso não se forma de maneira independente. Para compreender como os discursos que habitam o mesmo espaço se formam é necessário relacioná-los, considerando suas regras.

Em nossas reflexões, tomaremos o interdiscurso como a principal zona a ser trabalhada nas análises, uma vez que o foco central dos trabalhos recairá sobre a interação entre formações discursivas concorrentes. Considerando a vasta heterogeneidade do campo discursivo do entretenimento, selecionamos duas crônicas que versam sobre a mesma temática, constituindo assim o nosso espaço de investigação. Maingueneau (2015) esclarece que a formação discursiva é concebida como um sistema de restrições oculto, transversal às unidades tópicas. $\mathrm{O}$ interesse dessa noção é permitir constituir corpora heterogêneos. A demarcação desse sistema pelo analista se condiciona à maneira pela qual se conduz uma pesquisa, bem como aos resultados visados. Uma formação discursiva temática é delimitada, especificamente, a partir de um tema (do que se fala). Nesta pesquisa, consideramos que o tema "amor" é chave na sociedade e atravessa campos discursivos diversos. Temos de um lado o discurso romântico de EP e do outro o discurso realista de EA, ambos lutando para manter o domínio. 


\section{A noção de polêmica como interincompreensão para Maingueneau}

Tomando o espaço do discurso como uma rede de interação semântica, Maingueneau (2005) elegeu o processo de interincompreensão generalizada como a própria condição para as diferentes possibilidades de emergência das posições enunciativas. Os discursos são delimitados por grades semânticas específicas, o que necessariamente gera um liame para o desentendimento recíproco. Para eleger um sentido estrito é necessário sacrificar outros, consequentemente, os sujeitos da enunciação podem entrar em situações de confronto ou adesão na interação, em razão da natureza distinta de suas formações discursivas. Diante de um discurso determinado, duas formações discursivas diferentes podem interagir com o outro na tentativa de integrá-lo ou de rejeitá-lo. "É necessário precisar que há discursos cuja semântica exige crucialmente a pluralidade dos discursos, e outros que só podem funcionar reivindicando o monopólio da legitimidade" (MAINGUENEAU, 2005, p. 111).

A noção de interincompreensão polêmica foi sistematizada por Maingueneau (2005) com base na contraposição entre a formação de semas positivos e negativos no interior de um espaço discursivo dado - enquanto os primeiros são reivindicados, os segundos são rejeitados. No interior do espaço interdiscursivo são promovidos os embates entre as formações discursivas antagônicas, as quais permanecem em constante concorrência. Na perspectiva do autor, cada posição discursiva opera com base em um sistema específico, o qual pressupõe um determinado fechamento semântico, isto quer dizer que cada formação discursiva possui o seu modo particular de interpretar o seu outro. Dessa maneira, é possível que ocorra a tradução do outro pelo mesmo - graças à alteridade e ao antagonismo entre dois posicionamentos que se chocam. 
Quando um discurso traduz os semas do outro a partir do registro negativo de seu próprio sistema ocorre um embate, ou seja, uma polêmica, a qual é retratada por Maingueneau (2005) como um gesto capital, que cria situações irreversíveis e múltiplas possibilidades enunciativas. $\mathrm{O}$ autor declara que o mesmo pode se posicionar frente ao outro pelo viés interdiscursivo (heterogeneidade constitutiva) ou de maneira explícita (heterogeneidade mostrada). Perante essas estratégias, reside um nível dialógico, que concerne ao primeiro caso e outro propriamente polêmico, que se responsabiliza pelo segundo. As formas mostradas, como a citação por exemplo, explicitam a presença do outro como um corpo estranho no fio discursivo.

Maingueneau (2005, p. 103, itálico do autor) discrimina em discurso agente "aquele que se encontra em posição de tradutor" e discurso paciente "aquele que é assim traduzido", nesses casos, a tradução é efetivada com base na grade semântica do discurso agente. Em suma, um processo de tradução ocorre entre formações discursivas diferentes, trata-se da maneira como o mesmo pode aceitar ou renegar o outro. Relacionando a sistematização proposta pelo linguista aos dados dessa pesquisa, vislumbramos o discurso assumido por Rafinha Bastos como o agente, e é a partir do registro negativo de sua rede semântica que os semas do discurso construído por Gregório Duvivier (paciente) é traduzido. No caso analisado, Rafinha Bastos deixa claro o lugar do outro em seu discurso, construindo uma espécie de resposta a ele. Por conseguinte, a construção desse "discurso-resposta" revela o processo de leitura interincompreensiva concretizado pelo humorista, o qual procura explicitar ao leitor potencial a suposta incoerência do primeiro discurso.

Cano \& Celestino (2014) defendem que a questão dos semas é central para compreender a noção de polêmica da interincompre- 
ensão de Maingueneau. Os semas seriam unidades de significação mínima e para trabalha-los, na perspectiva da Análise Sêmica, seria necessário partir de um conjunto de semelhanças e diferenças. A metodologia deste trabalho se apoiou nessa afirmação no momento de identificar e analisar as estratégias linguístico-discursivas de tradução do sentido do material. Falamos em tradução, pois o EA significou os dizeres do EP a partir de sua própria grade sêmica, independente do sentido visado por EP. Comparamos os dois textos para analisar as traduções de sentido, mais especificamente, os enunciados pelos quais EA procurou renegar o posicionamento de $\mathrm{EP}$, expondo os seus limites e as suas diferenças.

\section{Por que um diz amor e o outro "amor"? uma ques- tão de ethos}

Quando pesquisamos a construção de imagens de si, imediatamente retomamos as discussões aristotélicas sobre o ethos como um dos componentes da retórica. De fato, essa noção possui um espaço relevante no campo filosófico e ganhou considerável notoriedade nos estudos pragmáticos, sendo retomada por muitos autores concentrados nos estudos discursivos. Por exemplo, desde os anos 1980 Dominique Maingueneau têm desenvolvido essa questão.

Maingueneau (2008) alerta que esse princípio é demasiadamente delicado por apresentar alguns problemas e inúmeras variações. Desta maneira, ele optou por uma versão mais "encarnada" para defini-lo, sem negar as contribuições aristotélicas. O linguista apontou que o ethos refere-se a uma dimensão verbal e também ao "[...] conjunto das determinações físicas e psíquicas associadas ao "fiador" pelas representações coletivas" (MAINGUENEAU, 2008, p. 65). O ethos propriamente dito seria elaborado por meio de uma 
percepção complexa que mobilizaria a afetividade do público. No caso, o destinatário retiraria as suas informações do material linguístico e do ambiente em que se encontra para compor uma imagem do enunciador. Nesse movimento, a figura constituída do fiador pelo destinatário traria à baila um mundo ético associado a comportamentos estereotípicos: "De fato, o fiador implica a ele mesmo um "mundo ético" do qual ele é parte pregnante e ao qual ele dá acesso” (MAINGUENEAU, 2008, p. 65). Maingueneau (2008) defende ainda, que o ethos constituiria um dos componentes da cena da enunciação. De acordo com a sua teoria, o discurso implica certa situação de enunciação, um ethos e um código linguageiro, através dos quais um mundo é configurado, ou seja, a encenação da enunciação realiza-se por meio de um investimento cenográfico, um código linguageiro e uma voz atestada por um corpo.

Maingueneau (2010) afirma que o ethos é coextensivo a toda enunciação. Enquanto o destinatário é levado a construir uma representação do enunciador, esse último procura controlar essa ação, nas palavras do autor, de forma "mais ou menos consciente e de maneira bastante variável, segundo os gêneros do discurso" (MAINGUENEAU, 2010, p. 79). Ao analisar o ethos de internautas em anúncios de sites de relacionamento, Maingueneau (2010) primou por observar as estratégias empregadas pelos internautas para construir uma imagem de si na enunciação e, ao mesmo tempo, para configurar um universo de sentido referente a essa imagem. No percurso metodológico dessa análise, ele delineou como os enunciadores se apresentam nos textos, considerando a particularidade do gênero empregado e as maneiras pelas quais o ethos se manifesta, seja por meio do ethos propriamente dito (expresso com informações diretas sobre si), do ethos mostrado (construído através de índices da enunciação) ou também do ethos construído a partir de fotos e imagens. 
Em nossos escritos, tomamos o ethos como aquilo que o enunciador mostra de si em decorrência de suas práticas discursivas e enveredamos por uma metodologia similar à usada por Maingueneau (2010). No entanto, acatamos as particularidades de nossos objetivos de pesquisa. Nos próximos dois subitens, verificamos como cada comediante exprimiu uma imagem de si ao publicar a sua crônica na Web; focalizamos as particularidades do gênero em questão, os índices da enunciação que denotam o ethos mostrado e a construção de cenografias. Relacionar ethos e interincompreensão polêmica é justificável neste contexto, pois partimos da hipótese de que a construção de uma imagem vendável de si foi uma das finalidades dos textos em ambos os contextos de aparição (tanto na publicação jornalística, quanto no site de relacionamento) e a interincompreensão polêmica foi empregada como uma estratégia para que os posicionamentos antagônicos dos comediantes fossem expostos ao público.

\section{A linha discursiva do comediante politicamente} correto

A crônica do enunciador paciente, intitulada "Desculpe o transtorno, preciso falar da Clarice", foi assinada pelo humorista brasileiro Gregório Duvivier no jornal virtual Folha de São Pau$l o^{4}$ em agosto do ano de 2016. Ao longo da carreira, Gregório trabalhou como ator, escritor e roteirista. Ficou conhecido na mídia brasileira por ser um dos criadores da série Porta dos Fundos, inicialmente veiculada pelo site youtube.com. Destacamos também os seus trabalhos como literato, bem aceitos pela crítica de maneira

4 Disponível em: <http://www1.folha.uol.com.br/colunas/gregorioduvivier/2016/09/1812342-desculpe-o-transtorno-preciso-falar-da-clarice.shtml> Acesso em 14 out. 2016. 
geral. A linha de atuação desse artista tende a adentrar o âmbito d $a$ crítica social e é direcionada a questões diversas, como a política, a religião, as relações de gênero. Em uma entrevista para o jornalista Diego Ponce de León, publicada em 2014 no Correio Braziliense ${ }^{5}$, o humorista afirmou que o seu trabalho é direcionado à luta contra as diversas formas de fascismo. Gregório considera que o humor que ele e os seus colegas de trabalho consolidam no Porta dos Fundos pode ser considerado politicamente correto e responsável. Observamos que a linha discursiva adotada por ele integra-o a um mundo ético politicamente correto, pois os seus posicionamentos aliam-se à crítica social como forma de provocar reflexões no público e a subverter verdades estabelecidas.

A ex-companheira de Gregório, personagem da crônica, conhecida como Clarice Falcão, também atua no meio midiático em uma linha similar à de Gregório. Salientamos que a crônica em questão, a qual teve como tema a sua história de amor com Clarice, foi publicada no mês anterior ao lançamento do filme "Desculpe o transtorno", protagonizado pelo casal (15 de setembro de 2016). Ao escrever a crônica, o enunciador desempenhava o papel social de um colunista da Folha, o qual possui as suas restrições sociais e profissionais. Uma crônica jornalística possui a característica de apresentar ao público fatos cotidianos e rotineiros, apesar de o autor possuir liberdade para expressar os seus pontos de vista e sentimentos ou usar o humor, relatando acontecimentos da própria vida, o texto deve procurar manter um assunto de interesse geral. Assim, a apresentação de si não é uma finalidade explícita, como em um anúncio de site de relacionamento, por exemplo. Apresentamos a seguir, algumas evidências do material linguístico-discursivo que apontam para a construção do ethos do comediante:

5 Disponível em: <http://www.correiobraziliense.com.br/ap/noticia/diversao-earte/2014/03/13/interna_diversao_arte,417179/ao-correio-gregorio-duvivier-questiona-a-televisao-e-aborda-as-polemicas.shtml> Acesso em 14 out. 2016. 
(1) Das dez músicas que mais gosto, sete foi ela que me mostrou. As outras três foi ela que compôs.

(2) Essa frase pode parecer romântica se você imaginar alguém tocando Cole Porter num subsolo esfumaçado de Nova York.

(3) Fizemos todas as receitas existentes de risoto. Queimamos algumas panelas de comida porque a conversa tava boa. Escolhemos móveis sem pesquisar se eles passavam pela porta.

(4) Foi paixão à primeira vista. Só pra mim, acho.

(5) Passamos algumas madrugadas conversando no ICQ ao som de Blink 182 e Goo Goo Dolls. De lá, migramos pro MSN. Do MSN pro Orkut, do Orkut pro inbox, do inbox pro SMS.

(6) Aprendi o que era feminismo e também o que era cisgênero, gas lighting, heteronormatividade, mansplaining e outras palavras que o Word tá sublinhando de vermelho porque o Word não teve a sorte de ser casado com ela.

(7) Escrevemos juntos séries, peças de teatro, filmes. Fizemos uma dúzia de amigos novos e junto com eles o Porta dos Fundos. Fizemos mais de 50 curtas só nós dois acabei de contar.

(8) Parece que, pra sempre, ela vai fazer falta. Se ao menos a gente tivesse tido um filho, eu penso. Levaria pra sempre ela comigo. 
Constatamos que o colunista da Folha, investido em seu papel de cronista, atuou discursivamente exaltando a figura de sua ex e do relacionamento que eles viveram em (1). No decorrer do texto, construiu cenografias românticas e requintadas, mais comuns a um público de classe média a alta, como é possível observar em (2). Em (3), o enunciador suscitou cenários cotidianos demonstrando o seu companheirismo. Já em (4), apresentou noções clássicas relacionadas à temática amor, como a noção do amor à primeira vista e do amor platônico. Outra evidência que observamos no material linguístico, em (5), foi a presença de referências e de palavras estrangeiras as quais denotam o acesso ao ambiente globalizado constituído através da cibercultura. Vislumbramos também, um tom de engajamento político marcado em uma fala democrática no discurso de Gregório, o qual abordou questões relacionadas à diversidade sexual em (6). Ao expor o que aprendeu com a ex, o comediante permitiu que o público constatasse como ele respeita a diversidade de gênero. $O$ cronista também expôs no texto a sua competência como profissional, quando citou os trabalhos concretizados por ele e pela ex em (7). O enunciador também expôs a sua posição de abandono em (8), pois relatou a falta que sente de Clarice. Essa posição pode representar uma tentativa de conquistar a solidariedade do público, pois apesar de ele ter se mostrado tão apaixonado e admirador da ex, não se relaciona mais com ela.

A partir dos dados linguístico-discursivos destacados, observamos que o enunciador expôs traços estereotípicos de um homem sensível e apaixonado, o qual pode ser associado a um tipo ideal de comportamento, pois circula na crença popular o estereótipo do "homem perfeito". Essa associação possível, indexada transversalmente pelo bojo interdiscursivo, expõe um posicionamento atraente ao universo feminino. De maneira geral, observamos que a enunciação concretizada por Duvivier construiu um ethos politicamente correto. O texto expôs ao público um homem 
apaixonado, admirador das mulheres, respeitador das diferenças, bem informado, competente, inserido no ambiente da cibercultura e abandonado. Até mesmo o fato de ele ter sido abandonado pode ser significado a partir de semas positivos, se associado à ideia de solidariedade e de maternidade. Por sua atuação, é possível que muitos leitores escolham aderir ao posicionamento do enunciador, visto que ele se apoiou em semas comuns e positivos para versar sobre a temática amor e para compor um ethos positivo.

\section{A linha discursiva do comediante transgressor}

Quanto à segunda crônica "Desculpe o transtorno, Gregório. Preciso muito falar da Júnia", foi escrita e publicada na rede social Facebook pelo também humorista brasileiro Rafinha Bastos. Tal humorista, ator, jornalista, empresário e apresentador se destacou na carreira com apresentações do estilo stand up e através da Internet, em redes sociais. Posteriormente, o humorista ganhou espaço na rede televisiva do país. Assim como outros humoristas brasileiros, Rafinha Bastos enfrentou diversos embates judiciais devido ao teor de suas piadas e declarações. De acordo com o noticiário do site da Secretaria de Políticas para as Mulheres ${ }^{6}$, o Ministério Público de São Paulo solicitou a abertura de um inquérito policial para apurar a suposta incitação ao estupro e à violência contra a mulher, cometida através de suas piadas. Pelo mesmo motivo, a Secretaria de Políticas para as Mulheres chegou a expedir uma nota de repúdio contra as piadas do humorista. Outra ocorrência que gerou um problema judicial à Rafinha Bastos, aconteceu no ano de 2011 quando o apresentador enunciou uma piada considerada ofensiva no programa televisivo Custe o que Custar (CQC) da 6 Disponível em: <http://www.spm.gov.br/area-imprensa/ultimas_noticias/2011/07/mp-pede-investiga-cao-de-humorista-por-piada-sobre-estupro> Acesso em 14 de out. de 2016. 
Rede Bandeirantes de Televisão (BAND). De acordo com o Recurso Especial número 1.487.089 $\mathrm{SP}^{7}$, a declaração do comediante foi considerada como dano moral e o réu foi obrigado a pagar uma indenização à acusação.

Constatamos que a linha discursiva adotada por Rafinha Bastos o integra a um mundo ético transgressor. Como é possível observar pelos processos enfrentados por ele, a sua forma de interagir com o público passa pelo extremismo. A imagem de si atribuída a esse humorista pode ser associada a um espaço do riso grotesco, sarcástico e que vai de encontro a padrões de comportamento legitimados como éticos e morais. Em síntese, o humorista atua em um espaço discursivo marginalizado, mas que possui um público que se sente envolvido com suas atitudes transgressoras. Por meio do riso, esse público confirma essa falta de legitimidade moral, ironicamente apreciada e consumida. Em relação à delineação do ethos no material linguístico-discursivo produzido, observamos que Rafinha Bastos atuou no facebook como um crítico da crônica de Duvivier. Apesar de ele ter escrito uma crônica aos moldes do outro artista, o ambiente em que ela foi postada (página pessoal do facebook) possui restrições e características diferentes de um jornal. Não necessariamente, o enunciador precisaria focar em um assunto geral, pois a apresentação de si seria uma das finalidades específicas de seu texto. Deste modo, é possível verificar pelo material linguístico-discursivo que o seu posicionamento é explicitado de maneira mais assertiva:

(1) Desculpe o transtorno, Gregorio. Preciso muito falar da Júnia. por Rafinha Bastos. Meu amigo, Gregorio Duvivier. Li a tua declaração de amor a Clarice na Folha [...] A minha visão de "amor de verdade" é bem diferen-

7 Disponível em: <http://www.stj.jus.br/static_files/STJ/Midias/arquivos/Noticias/REsp\%201487089.pdf> Acesso em 14 de out. de 2016. 
te. Permita-me contar a minha história.

(2) A primeira vez que nos vimos, foi numa balada alternativa (pra não dizer dos infernos) no centro de São Paulo.

(3) Foi quando do meio daquele cenário de destruição, ela apareceu. Foi como se uma sereia tivesse saído do rio Tietê.

(4) Pra mim, amor de verdade não é jazz, gastronomia e nem debate sobre cisgênero. Amor de verdade é brigar pelo lençol, é disputar o carregador de bateria e ficar puto quando o outro não atende o celular.

(5) Eu tinha 3 opções: o travesti que fazia cover da Madonna, a tiazinha da limpeza ou a Diolinda, chefe do caixa (que depois virou minha amiga). Foi quando no meio daquele cenário de destruição, ela apareceu.

(6) A entrada dela na minha vida era quase uma necessidade (na verdade eu meio que namorava com uma striper, mas não vale o destaque. Uma amiga me contou que ela deu uma facada num cara... sei lá. Uma mulher muito estranha).

(7) A pessoa com quem eu sei que posso contar. A mulher que me deu um filho. $O$ amor da minha vida (e mais todas as frases feitas que você possa imaginar).

(8) A Júnia foi, é ainda é, a minha parceira.

Averiguamos o status de resposta da crônica logo em seu título e parágrafo inicial. Em (1), o nome do outro colunista foi citado 
e Rafinha pediu permissão a ele para contar a sua história. Desde o início da crônica, ele deixou claro ao público que estabeleceria uma relação de contrariedade com o primeiro texto, reafirmando a sua posição contestadora, a qual é demarcada de maneira assertiva quando ele explica que não concorda com a versão de amor defendida por Gregório. De modo contrário à primeira crônica, onde um cenário clássico foi delineado, na segunda crônica o enunciador agente criou cenários grotescos, como observamos em (2) e (3). Ainda no enunciado 3, ele desvalorizou o travesti e as funcionárias do estabelecimento, pois estes personagens integrariam o que ele chama de cenário de destruição. Ao contar como conheceu Júnia, em (5), e sobre um relacionamento que manteve anteriormente, em (6), o enunciador expôs, indiretamente, as suas concepções a respeito do universo feminino ao público. Quando ele contou sobre o bar onde conheceu a esposa, colocou-se em uma posição de poder em relação às mulheres, pois poderia escolher entre qualquer uma das opções existentes no local para ter um relacionamento. De maneira similar, desvalorizou a mulher com que se relacionava anteriormente, revelando um crime cometido por ela sem especificar as circunstâncias de tal, além de referenciá-la de maneira pejorativa.

Em (7), o enunciador demonstrou respeito pela esposa em função do seu comprometimento e por ter lhe dado um filho. Apesar de ter revelado detalhes sobre o seu relacionamento com Júnia, ela foi exposta como uma personagem secundária no texto. Por exemplo, Júnia livrou o personagem de um relacionamento ruim, de uma vida de vícios, da companhia de um pote de manteiga e deu um filho a ele, por esses motivos, ela foi considerada o amor de sua vida. Diferente de Gregório que se separou, o enunciador agente expôs ao público que Júnia ainda é a sua parceira em (8). Essa argumentação sustenta a justificativa de que a sua versão de amor é mais verdadeira do que a versão apresentada por Gregório. 
Em suma, observamos que a enunciação concretizada por Rafinha Bastos com a crônica construiu um ethos de transgressor. $\mathrm{O}$ texto expôs ao público um internauta extravagante, pouco respeitador das mulheres e das diferenças, crítico, anteriormente envolvido com o uso de drogas e pouco romântico. Todavia, ao contar sobre as suas experiências, ele se mostrou como um companheiro do dia a dia, presente tanto em momentos bons, quantos ruins. Dessa forma, atestou a sua posição como detentor da verdade e como um cidadão comum, parecido com o público, uma vez que relacionou o amor a um plano empírico, onde palavras e ambientes marginalizados são aceitos. Apesar do posicionamento transgressor, a crônica escrita por Rafinha Bastos pode ser avaliada positivamente, se o público se identificar com uma grade sêmica onde o grotesco é considerado engraçado. Além do mais, os cenários ideais e românticos descritos por Duvivier podem estar muito distantes da realidade do público ideal de Rafinha.

\section{Análise do processo de tradução}

A produção de simulacros do discurso agente em relação ao paciente foi concretizada, na maioria dos casos analisados, por meio de relações de contrariedade. Tomamos por tradução a ação de modificar a grade sêmica de um discurso primeiro, com base em Maingueneau (2005). Como explicitamos a seguir, EA tomou os dizeres de um discurso primeiro e os interpretou de acordo com os semas de sua própria grade semântica, na intenção de torná-los negativos. Na sequência, representamos dois quadros que exemplificam as traduções efetivadas pelo discurso agente em relação ao paciente e a análise de seis enunciados: 


\begin{tabular}{|c|c|c|}
\hline & Discurso Paciente & Discurso Agente \\
\hline & $\begin{array}{l}\text { "Desculpe o transtorno, preciso } \\
\text { falar da Clarice" }\end{array}$ & $\begin{array}{l}\text { "Desculpe o transtorno, Gregorio. } \\
\text { Preciso muito falar da Júnia". }\end{array}$ \\
\hline 1 & $\begin{array}{l}\text { Conheci ela no jazz. [...] Mas o jazz } \\
\text { em questão era aquela aula de dan- } \\
\text { ça que todas as garotas faziam nos } \\
\text { anos } 1990 \text {-onde ouvia-se tudo } \\
\text { menos jazz. Ela fazia jazz. Minha } \\
\text { irmã fazia jazz. Eu não fazia jazz } \\
\text { mas ia buscar minha irmã no jazz. } \\
\text { Ela estava lá. Dançando. Nunca } \\
\text { vou me esquecer: a música era } \\
\text { "You Oughta Know", da Alanis. }\end{array}$ & $\begin{array}{l}\text { Não conheci ela no jazz, na infância } \\
\text { nem no ICQ. A primeira vez que nos } \\
\text { vimos, foi numa balada alternativa (pra } \\
\text { não dizer dos infernos) no centro de } \\
\text { São Paulo. }\end{array}$ \\
\hline 2 & $\begin{array}{l}\text { Essa frase pode parecer romântica } \\
\text { se você imaginar alguém tocando } \\
\text { Cole Porter num subsolo esfuma- } \\
\text { çado de Nova York. }\end{array}$ & $\begin{array}{l}\text { Foi quando do meio daquele cenário } \\
\text { de destruição, ela apareceu. Foi como } \\
\text { se uma sereia tivesse saído do rio Tietê. }\end{array}$ \\
\hline 3 & $\begin{array}{l}\text { Passamos algumas madrugadas } \\
\text { conversando no ICQ ao som de } \\
\text { Blink } 182 \text { e Goo Goo Dolls. De } \\
\text { lá, migramos pro MSN. Do MSN } \\
\text { pro Orkut, do Orkut pro inbox, do } \\
\text { inbox pro SMS. }\end{array}$ & $\begin{array}{l}\text { Ficamos uma, duas, três vezes. Na quar- } \\
\text { ta ela se mudou pra minha casa. Eu não } \\
\text { questionei. }\end{array}$ \\
\hline 4 & $\begin{array}{l}\text { Um dia, terminamos. E não foi fá- } \\
\text { cil. }\end{array}$ & $\begin{array}{l}\text { Rapidamente me dei conta de que aqui- } \\
\text { lo era de verdade. A Júnia foi, é ainda é, } \\
\text { a minha parceira. A pessoa com quem } \\
\text { eu sei que posso contar. }\end{array}$ \\
\hline 5 & $\begin{array}{l}\text { Se ao menos a gente tivesse tido } \\
\text { um filho, eu penso. Levaria pra } \\
\text { sempre ela comigo. }\end{array}$ & $\begin{array}{l}\text { A mulher que me deu um filho. O amor } \\
\text { da minha vida (e mais todas as frases } \\
\text { feitas que você possa imaginar). }\end{array}$ \\
\hline 6 & $\begin{array}{l}\text { Fizemos todas as receitas existen- } \\
\text { tes de risoto. Queimamos algumas } \\
\text { panelas de comida porque a con- } \\
\text { versa tava boa. }\end{array}$ & $\begin{array}{l}\text { A gente tentou fazer a um risoto uma } \\
\text { vez, mas queimou. Ela colocou a culpa } \\
\text { em mim. Eu fiquei puto e saí de casa. } \\
\text { Comi um yakissoba na esquina. Ela me } \\
\text { ligou } 1 \text { hora depois e pediu pra eu levar } \\
\text { um hamburguer. Eu comprei... e comi } \\
\text { no caminho. Passei mal. }\end{array}$ \\
\hline
\end{tabular}

Quadro 1 - Relações de contrariedade

Fonte: Elaborado pelos autores. 


\begin{tabular}{|l|l|l|l|}
\hline Discurso paciente & Discurso agente & $\begin{array}{l}\text { Após a interação entre as duas crô- } \\
\text { nicas }\end{array}$ \\
\hline $\begin{array}{l}\text { "Desculpe o } \\
\text { transtorno, preciso } \\
\text { falar da Clarice" }\end{array}$ & $\begin{array}{l}\text { "Desculpe o } \\
\text { transtorno, } \\
\text { Gregório. } \\
\text { Preciso muito } \\
\text { falar da Júnia". }\end{array}$ & Zona do interdiscurso \\
\hline $\mathrm{M}+$ & $\mathrm{M}+$ & $\begin{array}{l}\text { Discurso paciente } \\
\text { M - }\end{array}$ & $\begin{array}{l}\text { Discurso agente } \\
\text { M + }\end{array}$ \\
\hline Cult & Popular & Irreal & Realista \\
\hline Requintado & Poluído & Distante & Factível \\
\hline Inocência & Maturidade & Distanciamento & Proximidade \\
\hline Dificuldade & Presença & Fracasso & Sucesso \\
\hline Nostalgia & Compromisso & Ilusório & Certeza \\
\hline Tradicional & Inusitado & Idealizado & Moderno \\
\hline
\end{tabular}

Quadro 2 - Análise das traduções

Fonte: Elaborado pelos autores.

A partir da coluna 1 do Quadro 1, constatamos que o EA expôs o outro em seu dizer quando revelou onde conheceu a esposa. Tal exposição é localizável por meio da negação do ambiente proposto pela primeira crônica e pela presença dos mesmos vocábulos empregados pelo EP (jazz e ICQ). Deste modo, o discurso agente traduziu a forma como o EP conheceu a esposa como irreal. A contradição pode ser vislumbrada pela polarização dos ambientes propostos por um e outro - o cenário cult descrito pelo EP foi traduzido como irreal. Em contrapartida, o cenário comum descrito pelo EA assumiu a significação de real.

Na coluna 2 do Quadro 1, evidenciamos a escolha do EA pela associação da temática amor a um ambiente popular e urbano. Ele referenciou o conhecido elemento metropolitano, o rio Tietê, conhecido por ser extremamente poluído, o que alude à precariedade do cenário em que encontrou a esposa. De outra forma, apesar de 
ter afirmado que o local onde a conheceu não se tratava de um subsolo esfumaçado de Nova York, ao empregar essas referências, o EP suscitou um ambiente requintado e estrangeiro. Em vista disto, surgiram as relações de contrariedade, pois o discurso agente traduziu o requinte do ambiente descrito pelo EP como distante, enquanto o local em que o EA conheceu a esposa assumiu a significação de factível.

Observamos na coluna 3 do Quadro 1 a demarcação de uma diferença entre um relacionamento adulto e outro adolescente. Nesse trecho, o EA afirmou que a esposa se mudou para a casa dele rapidamente, enquanto o EP descreveu uma relação amorosa mediada por instrumentos de comunicação diversos, como as redes sociais e os serviços de telefonia, demarcando o comportamento conhecido como nerd no senso comum. Ao contrastar as relações, o discurso agente atuou traduzindo a inocência representada pelo EP como um tipo de distanciamento imaturo, a partir da exaltação do comportamento mais maduro do seu relacionamento.

Ao afirmar que percebeu a concretude do relacionamento na coluna 4 do Quadro 1, o EA ratificou que a sua esposa permaneceu sempre ao seu lado. Essa situação se mostra contrária à narrada pelo EP, o qual revelou o fim do relacionamento e a falta que sente da ex. Desta maneira, o discurso agente traduziu a dificuldade do término do relacionamento representado pelo EP como fracasso. Já a presença da esposa do EA em sua vida foi significada como sucesso.

Na coluna 5 do Quadro 1, o EA atestou que a mulher lhe deu um filho. Ao verbalizar este fato, dirigiu-se diretamente ao EP (simulação de um diálogo direto) por meio da presença do vocábulo você. Essa ação concretizou uma crítica direta ao EP e serviu ao propósito de demarcar diretamente a negação do romantismo. Assim, a nostalgia proposta pelo EP foi traduzida como ilusão e o compromisso descrito pelo EA assumiu a significação de certeza. 
Na coluna 6 do Quadro 1, observamos que o EA contrapôs o relato cotidiano representado pelo EP. Na versão do discurso agente, $\mathrm{o}$ ato de cozinhar em casa com a esposa não foi agradável e teve um final praticamente trágico. Nesse sentido, o discurso agente traduziu a atitude tradicional representada pelo EP como idealizada. Em contraponto, apoiou-se em uma situação inusitada para significar a sua versão como moderna.

Por fim, assinalamos que a leitura outra construída pelo EA promoveu um choque entre posicionamentos diferentes, produzindo efeitos de sentido que visam à exaltação das diferenças entre um e outro. Desta maneira, os semas do discurso paciente foram traduzidos a partir da rede semântica do discurso agente por meio de relações de contrariedade.

\section{Considerações finais}

O exame do material demonstrou que o segundo comediante simulou uma espécie de diálogo com o primeiro cronista na procura de exibir o seu ponto de vista para o público em geral. Falamos em diálogo simulado porque o interesse não estaria direcionado a uma resposta imediata e sim à defesa de um posicionamento e à construção de uma imagem vendável de si. As ações de EA caracterizaram uma estratégia de leitura que privilegiou a exaltação da polêmica como interincompreensão. A contraposição das ideias terminou por descreditar o discurso primeiro. Concluímos que o choque instaurado entre os posicionamentos concorrentes dentro de uma formação discursiva temática pode ser associado à imagem de si dos enunciadores, os quais atuaram no espaço cibernético não somente na busca de defender os seus pontos de vista, mas também pela captação do público. 
Ademais, ressaltamos que ao ressignificar um discurso primeiro a partir de uma grade sêmica em que o amor é representado de forma realista, o EA requereu uma via de significação onde o discurso marginal pode ser aceito, situação intimamente ligada ao caráter democrático do ambiente virtual, no qual há espaço para que o grotesco seja significado positivamente, por ser mais real e próximo da vida cotidiana do público. Outrossim, as reflexões referentes às estratégias linguístico-discursivas de tradução realizadas pelo EA em relação ao discurso primeiro, revelaram a concorrência dos sentidos que habitam a zona do interdiscurso, cujos indícios foram recuperados por meio da contraposição de ideias por alusão (heterogeneidade constitutiva) e da negação verbal do outro (heterogeneidade mostrada).

A análise do embate discursivo realizada por esse trabalho suscita questões diretamente relacionadas à formação de leitores competentes para a compreensão dos complexos diálogos travados no meio virtual, os quais são marcados pelo jogo da presença e da ausência, pela multiplicidade de coenunciadores, pela construção de imagens de si e pela luta entre posicionamentos. Partindo do pressuposto de que o sentido é construído socialmente nas diversas situações discursivas, ressaltamos as inúmeras possibilidades que o espaço virtual pode oferecer para tal. 


\section{Referências}

AUTHIER-REVUZ, Jacqueline. Heterogeneidade (s) enunciativa (s). Cadernos de estudos linguísticos. Campinas, v. 19,1990, p. $25-$ 42.

CANO, Márcio Rogério de Oliveira; CELESTINO, Ricardo. Regulamentação e controle: a polêmica da interincompreensão em discursos sobre a maconha. Revista interseções. Rio de Janeiro, v. 13, n. 2 -2014, p. 168-186.

EMEDIATO, Wander. Discurso e Web: as múltiplas faces do facebook. Revista da ABRALIN. Curitiba, v. 14, n. 2, 2015, p. 171-192. LÈVY, Pierre. Cibercultura. 3. ed. Tradução Carlos Irineu da Costa. São Paulo: 34, 1999.

MAINGUENEAU, Dominique. Gênese dos discursos. 1. ed. Tradução Sírio Possenti. São Paulo: Criar Edições, 2005.

MAINGUENEAU, Dominique. Cenas da enunciação. 2. ed. POSSENTI, Sírio; SOUZA-e-SILVA, Maria Cecília Perez de (Orgs.). São Paulo: Parábola, 2008.

MAINGUENEAU, Dominique. Dose conceitos em análise do discurso. 1. ed. POSSENTI, Sírio (Org.). Tradução Adail Sobral... [et al.]. São Paulo: Parábola, 2010.

MAINGUENEAU, Dominique. Discurso e análise do discurso. 1. ed. Tradução Sírio Possenti. São Paulo: Parábola, 2015.

ORLANDI, Eni Pulcinelli. Discurso e Leitura. 1. ed. São Paulo: Cortez, 1988. 